'||||||||||||||||||||||||||||||||||||||||||||||||||||||||||||.

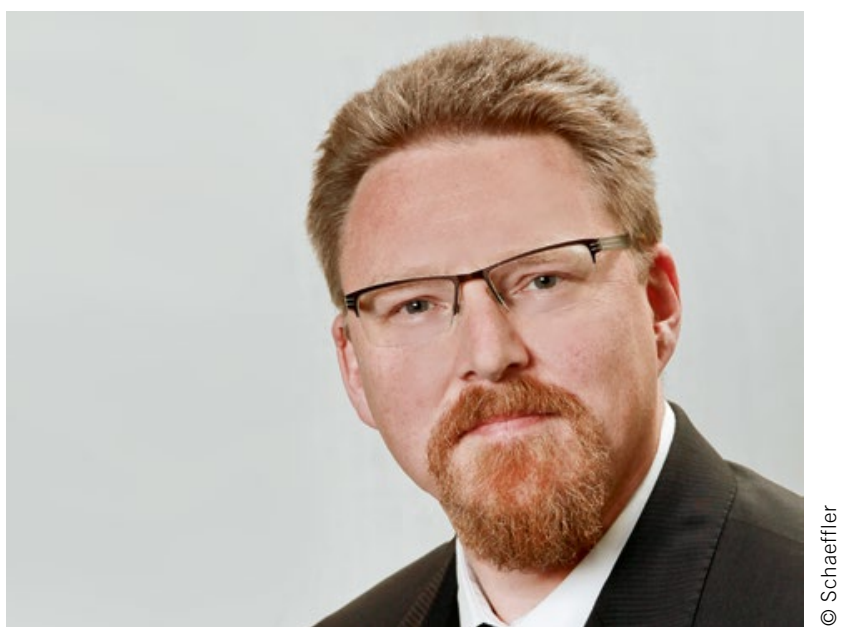

\section{Effizienz, Präzision und Zuverlässigkeit}

Effizienz, Präzision und Zuverlässigkeit - so lauten die drei Stichworte, wenn es um Nutzfahrzeuge aller Art von morgen geht. Dabei spielen unter anderem der möglichst effektive Einsatz von Ressourcen (Maschinen, Saaten etc.) und die Steigerung der Arbeitsgeschwindigkeit der Maschinen, zum Beispiel durch verbesserte Traktion bei gleichzeitig verbesserter Genauigkeit, eine zentrale Rolle. Damit einher geht die steigende Anzahl von intelligenten mechatronischen Systemen in den Fahrzeugen.

Parallel dazu dreht sich auch bei der (Weiter-)Entwicklung von Land-, Arbeitsmaschinen und Co. alles um die möglichst effiziente Verwendung von Brennstoffen bei steigenden gesetzlichen Emissionsanforderungen. Schließlich werden sich die zukünftigen Grenzwerte an die der Onroad-Nutzfahrzeuge anlehnen. Auch wird der $\mathrm{CO}_{2}$-Ausstoß der Antriebe eine Rolle spielen, das notwendige Monitoring dazu ist schon in der Diskussion oder hat bereits begonnen.

Der Einsatz von alternativen und erneuerbaren Energiequellen in den Antrieben der Agrarwirtschaft gewinnt an Bedeutung. Dies zeigen die Forschungs- und Entwicklungsaktivitäten in diesen Themenbereichen ebenso, wie bereits einzelne vorgestellte Produkte. Dabei ergibt sich die Notwendigkeit zu deren Einsatz aus verschiedenen Gesichtspunkten. Zum einen spielt auch hier die Effizienz eine Rolle die Agrardieselsubvention läuft in der derzeitigen Form zunächst nur bis Ende 2016. Zum anderen lassen sich Emissionen $\left(\mathrm{CO}_{2}\right.$, Partikel) durch die Verwendung von Erdgasen und Biokraftstoffen in monovalenten, bivalenten sowie Dual-FuelMotoren wirksam reduzieren. Ebenso ist damit eine autarke Energieversorgung des landwirtschaftlichen Betriebs möglich. Nicht zuletzt ist das Thema Zuverlässigkeit von Belang - robuste Technologien aus dem Nutzfahrzeugmotorenbereich stehen für den Transfer in den Offhighway-Bereich zur Verfügung.

\section{Efficiency, Precision and Reliability}

Efficiency, precision and reliability these are the three priorities for all the commercial vehicles of tomorrow. Among other things, a key role is played by the most effective use of resources (machines, seeds etc.) and an increase in the working speed of machines, for example by improved traction and precision. This is accompanied by a growing number of intelligent mechatronic systems in the vehicles.

At the same time, with respect to the (further) development of agricultural machines, working machines, etc. it is also important to make the most efficient use of fuels against a background of increasing emissions requirements. Ultimately, future limit values will be based on the values for on-road commercial vehicles. The drives' $\mathrm{CO}_{2}$ emissions will also play a role.

The use of alternative and renewable energy in drives for the agricultural sector is becoming more important. This is demonstrated by the related research and developement activities as well as by presented products. The necessity of their use arises from a variety of viewpoints. Firstly, efficiency also plays a role here the agrarian diesel subsidy will only run until the end of 2016 in its present form. Secondly, emissions ( $\mathrm{CO}_{2}$, particle) can be effectively reduced by using natural gases and biofuels in various engine concepts. This way, an autarchic energy supply for the agriculturist is possible.

Finally, the subject of reliability is important - robust technologies from the commercial vehicle engine sector are available for transfer to the off-highway sector. 